$\mathrm{ppm}$ 以上のAsを含有する試料では生体応用に適してい る。原子吸光分析法の As の最小検出は 0.5ppmで波長 は $1937 \AA$ であった。そこで現在いろいろな前処理法に より測定結果を検討中である。

\section{4 原子吸光分光分析法による鉛の定量について}

奥谷博俊，○原田 昭，松浦洋治

福井久雄, 工藤つや

(名书大公衛)

気中ならびに，血中，尿中鉛の定量法として，従来か らもちいられている dithizone 法は感度が高く，すぐ れているが，操作が繁雜で，集団検查用として，必ずし も適当であるとはいえない。このため，最近開発された 原子吸光分光分析法は操作が簡易で，短時間に多数の試 料処理ができるので，公衆衛生学領域における金属元素 の定量には有用であるとされている。てのたび，われわ れは Nippon jarrel-ash AA-1 型の装置について，鉛 定量の測定条件，感度，精度などを検討して，次の成績 をえた。なお，燃料は水素一空気をもちいた。

1) 測定条件：光源電流および検知器電圧は低いほど 感度が良いが，下げ過ぎると精度が落ちる。バーナーの 高さは本装置がマルチバス光学系を用いているため，は とんど感度に影響しない。燃料のガス圧は水装，空気と もに高い方が良いが，水素圧より空気圧をやや高めにす るのが望ましい。記録計は高感度に切り換えると，感度 は良くなるが，精度が落ちる。

2 ）感度および精度：試料として水溶液をもちい，0. $05 \gamma / \mathrm{cc}$ まで測定可能で, 硝酸溶液, ヨード・ヨードカリ 腹をもちいても，ほぼ同様の慧度がえられる。有機溶媒 中に鉛を抽出すると,感度はかなり上昇する。鉛添加試料 による定量值の再現性は実用上，充分満足することがで きる。また， dithizone 法の成績と比較した結果，添加 試料，気中鉛いずれについても，各種溶媒において，ほ ぽ一致した值をえた。

以上，原子吸光分光分析装置について，鉛定量の測定 条件，感度ならびに精度を明らかにし，公采衛生学領域 において，充分使用しうるととを明確にした。

\section{5 ステアリン酸鉛の原子吸光分析法による定量}

長谷川敬彦，○粟屋研吾，緒方正名（网大公䍉）

塩化ビニールの安定肪としてのスデリン酸鉛は，ビ ニール加工作業場に於ける鉛中毒の原因物質として重要 である。健康管理上作業者の尿中鉛排泄 量の测定と其 に，作業環境に於けるステアリン酸鉛の気中濃度の測定
はより重要な事と思われる。この場合測定は，ルーチン ワークに適する様に簡易性, 迅速性が望まれる。先に私 洪は原子吸光分析法による疛中鉛の測定について発表し たが，今回はステアリン酸鉛塩の原子吸光分析法による 湘定について検討した。

ステアリン酸鉛は，水，有機溶媒に不溶であるが氷酢 酸に可溶である。サンプルを水酐酸に浴かし $1 \% \mathrm{amm}$ onium pyrrolidine dithio carbamate を加光て chelate しさらに $1 \mathrm{~N}-\mathrm{NaOH}$ を加えて， pH 2.5〜3.0 にする。 この場合酐酸量に対して適当な茫性ソーダ量を定めてお けば, buffer system を自動的に作るので簡便である。

さらに A.P.D.C. Pb complex 皇 M.I.B.K. に転溶, 原子吸光分析にかける。この方法による回収率は100\%， $1 \%$ deff は 1ppm, 私共が開発した preheating burner では 0.05ppm であった。死化を必要としない点, 測定 の精度と感度が高い点, 操作の簡易な点が特徴である。

\section{6 某中小企業の鉛中毒管理について}

$$
\text { 勝野真周 （労衛センター） }
$$

某中小企業で，リサージ,鉛丹等を製造するA工場，三 塩基性硫酸鉛を製造するB工場，二塩基性ステアリン酸 鉛，Nーステアリン酸鉛を製造するC工場の従業員につ 鉛中毒管理を 6 年間継続してきたが，その成績をまと めてみると，環境条件，労働条件等は三工場ともほぼ同 ビレベルであるに拘わらず，A工場作業員の血液，尿所 見は他の工場作策貝に比して，鉛中毒を示す例が多く， これは取扱う鉛化合物の相違（リサージ取报はA工場の る）によるものと思われた。

特に，リサージ，鉛丹製造に就業していた作業員 4 名 は，配置転換，投薬治療で，一時的には所見が好転する 方，現場作羓復帰すると再び悪化し，治瘾と再発をく り返すような奏状となった。

たとえば，乙の中のA例は13年間就業していたが，い ろいろの处置にかかわらず，血液，尿所見が好転しない ため，C工場製造現場に配転させた。

しかし，1年経過後も所見が好転しないため，更に 1 作間非鉛作業に就業させた。との処置で血㳔数值は稍回 復したが，血中，㽷中鉛等はやはり許容量以上で，好塩 基点赤血球も減少しなかった。

他の3 例も略類似の所見で，乙れらの4例は鉛作業を はなれれば所見は稍回復するが，原職に復帰すると，再 び檼化すると云う共通な反応を示している。 以上の症例について，作羓暦，生活環境，個人素質， 